\title{
Amaranth - A Functional Food
}

\author{
Sushil Narwade ${ }^{1}$ and Suneeta Pinto ${ }^{2 *}$ \\ ${ }^{1}$ Dairy Technology Department, Anand Agricultural University, India \\ ${ }^{2}$ Anand Agricultural University, India
}

Received: 制 April 25, 2018; Published: 盋 May 11, 2018

*Corresponding author: Suneeta Pinto, Anand Agricultural University, India

\begin{abstract}
Amaranthus, collectively known as amaranth or pigweed, is a cosmopolitan genus of herbs. Approximately 60 species are presently recognized, with inflorescences and foliage ranging from purple and red to gold. Because of recent concerns about global food security and malnutrition scientists all over the world are engaged in exploring the plant biodiversity to broaden the crop list. Due to described agricultural advantages, unique nutritional properties and versatile usage, grain amaranth (Amaranthus spp.) has gained increased attention. Amaranth seeds have a high content of storage proteins (14-19\%) whose amino acid composition is rich in lysine and methionine, two limiting amino acids in cereals and legumes, respectively. Amaranth (Amaranthuscaudatus), quinoa (Chenopodium quinoa) and ka niwa (Chenopodiumpallidicaule) are originally from the Andes of South America where they have remained a staple since Pre-Hispanic times. Due to its good protein quality which is comparable to casein, high fibre content and bioactive compounds, and these gluten-free grains are formidable food alternatives for celiac patients and/or those suffering from gluten-sensitivity.
\end{abstract}

Keywords: Grain Amaranth; Nutrition Value; Utilization

\section{Introduction}

Amaranthus is recognized as a promising plant genus that may provide high-quality protein, unsaturated oil, and various other valuable constituents. Amaranths are valued as leaf vegetables and cereals.It is noted not only for its environmental hardiness but also for the excellent nutritional quality of its seeds (Bejosano, [1]). Due to its unique nutritional properties and versatile usage, grain amaranth (Amaranthus spp.) has gained increased attention. Amaranthus, collectively known as amaranth or pigweed, is a cosmopolitan genus of herbs. Approximately 60 species are presently recognized, with inflorescences and foliage ranging from purple and red to gold. Most species are considered as opportunistic weeds and only three of them, Amaranthuscaudatus, Amaranthuscruentus and Amaranthushypochondriacus, are commonly consumed by humans as a seed or used as a functional ingredient in foods (Gamel). Amaranth is a pseudocereal because of its flavor and cooking similarities to grains. The word "Amaranth" comes from the Greek amarantos, the 'one that does notwither' or the never-fading flower. It contains high content of fibre and bioactive compounds Repo-Carrasco [2], these gluten-free grains are formidable food alternatives for celiac patients and/or those suffering from gluten-sensitivity. It also provides a good source of dietary fiber and dietary minerals such as iron, magnesium, phosphorus, copper, and especially manganese. Amaranth was recognized as gluten-free and is therefore suitable for diets of celiac disease patients (Fasano and Catassi [3]; Thompson [4]. The seeds are eaten as a cereal grain. They are ground into flour, popped like popcorn, cooked into porridge, and made into a confectionery called alegría. The leaves can be cooked like spinach, and the seeds can be germinated into nutritious sprouts. The leaves are variable in size, green or purple, with slender stalks. These are alternate, usually simple, with entire margins and distinct markings, depending on species. Amaranth species are also cultivated and consumed as a leaf vegetable in many parts of the world. In India the leaf is added in preparation of a popular dal called thotakurapappu. In China the leaves and stems are used as a stir-fry vegetable. In East Africa amaranth leaf is known as mchicha- "a vegetable for all". The seeds are used as a source of lipids and a material for the production of flour, flakes, popped seeds, several sorts of bread (Januszewska-Jóźwiak and Synowiecki, [5]) and confectionery Sindhuja [6]. 


\section{Chemical Composition and Nutrition Value}

The small seeds are usually shiny black in colour, in contrast to those of grain types which are cream-coloured. There are up to 3000 seeds per gram. The tiny, lens shaped seeds are usually pale in colour.A seed of grain amaranth is on average composed of 13.1 to $21.0 \%$ of crude protein; 5.6 to $10.9 \%$ of crude fat; 48 to $69 \%$ of starch; 3.1 to $5.0 \%$ (14.2\%) of dietary fibre and 2.5 to $4.4 \%$ of ash Grobelnik [7]. Enzyme inhibitors and allergens are known to be present in cereals. Protein isolated from wheat, rice, maize and barley may cause allergic reaction, a gliadin fraction isolated from wheat causes celiac disease. But these components are not available in pseudocereals and legumes such as soybean and amaranths Kuhn [8]. Furthermore, amaranths contain dietary fibre in high proportion, which improves lipid metabolism. Its nutritional value is mainly due to its protein fraction (Gorinstein [9] Oleszek [10]). Amaranth, a pseudocereal, is an unconventional and interesting source of proteins. Its seeds contain a large amount (14-17\%, $\mathrm{w} / \mathrm{w}$ ) of high nutritional quality proteins (Bolontrade [11]), whose amino acid composition is rich in lysine and methionine, two limiting aminoacids in cereals and legumes, respectively [4,5]. Amaranth's balanced amino acid composition is close to the optimum protein reference pattern in the human diet according to FAO/ WHO requirements. Protein is high in amino acid lysine but low in leucine. This is the opposite of most other grains. Thus mixing would form an almost perfect protein (Good ratio of unsaturated fat to saturated fat that is beneficial for hypertension and coronary heart disease).The nutritional quality of amaranth seed is high because of its high protein content and balanced essential amino acid composition (Oszvald [12]). Moreover, amaranth grain protein is rich in lysine, which is usually deficient in cereal grains. Proteins have high digestibility (approx. 90\%) and are rich with lysine (4.9 to $6.1 \mathrm{~g} / 100$ g protein) which usually appears in grains as a limiting amino acid. This high lysine concentration is complemented with elevated levels of sulphur amino acid content ( 2 to $5 \%$ ), which is higher than that measured in the most important legumes $(1.4 \%$ on average), such as peas, beans and soybeans (Gorinstein and Moshe,
[13]). Leucine, isoleucine, valine, the limiting amino acids in amaranth, are not considered a serious problem since they are found in excess in most common grains, and therefore, amaranth is well suited for blending with cereals.The main protein fractions present in the amaranth grain are albumins, 11S-globulin, P-globulin, and glutelins .

Amaranth starch is of promising use. The features of starch like high solubility and digestibility are due to its uniquely small size which is about one-tenth the size of cornstarch and therefore offer new possibilities for food processing, pharmacology and cosmetics Resio [14]. The total mineral content has been reported to be generally higher than that observed in cereal grains, especially calcium and magnesium Alvarez-Jubete [15]. On the other hand, it is characterized by higher dietary fibre and lipid content than most cereals and also contains between 50 and $60 \mathrm{~g}$ of starch per $100 \mathrm{~g}$ of grains Alvarez-Jubete [15]. Amaranth has recently become a focus of interest for its high nutritive values and great potential as a functional food given its cholesterol-lowering effect observed in animal models Mendonça [16]; Plate \&Arêas [17]. According to Becker [18] seed of grain amaranth is a rich source of iron (72 to $174 \mathrm{mg} / \mathrm{kg}$ ), calcium $(1,300$ to $2,850 \mathrm{mg} / \mathrm{kg}$ ), sodium (160 to $480 \mathrm{mg} / \mathrm{kg}$ ), magnesium $(2,300$ to $3,360 \mathrm{mg} / \mathrm{kg}$ ) and zinc (36.2 to $40 \mathrm{mg} / \mathrm{kg}$ ) as well as vitamin riboflavin $(0.19$ to $0.23 \mathrm{mg} / 100 \mathrm{~g}$ of flour) ascorbic acid (4.5mg/100g), niacin (1.17 to $1.45 \mathrm{mg} / 100 \mathrm{~g})$, and thiamine $(0.07$ to $0.1 \mathrm{mg} / 100 \mathrm{~g}$ ). Amaranth oil is reported to have high levels of tocotrienols and squalene, which are natural organic compounds that are involved in the metabolism of cholesterol and that could play an important role in lowering LDL-cholesterol in blood. Amaranth lipid is unique with high squalene content ranging from 2.4 to $8.0 \%$ of the total oil contents (Rodas and Bressani, [19]. A comparative account of nutritive value of grain amaranths and other cereals is presented in Table 1 . On the average pale-seeded amaranths contain $8 \%$ of dietary fibre and black coloured $16 \%$ with soluble fibre rate of 30 to $40 \%$ and $18 \%$, respectively (Schnetzler and Breene [20], Tosi [21] reported $14.2 \%$ of dietary fibre in the A. cruentus flour (8.1\% soluble, $6.1 \%$ insoluble).

Table 1: Comparative account of nutritive value of grain amaranths and other cereals.

\begin{tabular}{|c|c|c|c|c|c|c|c|c|}
\hline Sr. No. & Crops & Protein & Fat & Carbohydrates & Calcium & Iron & Phosphorus & $\begin{array}{l}\text { Food energy } \\
\text { (Kcal/g) }\end{array}$ \\
\hline 1 & Amaranth & 16.0 & 3.1 & 60.0 & 0.49 & 17.5 & 0.60 & 391 \\
\hline 2 & Rye & 12.1 & 1.7 & 73.4 & 0.38 & 10.5 & 0.37 & 334 \\
\hline 3 & Buckwheat & 11.7 & 2.4 & 72.9 & 0.12 & 15.5 & 0.28 & 335 \\
\hline 4 & Chenopod & 12.0 & 5.0 & 68.0 & 0.20 & 12.6 & 0.50 & 342 \\
\hline 5 & Wheat & 13.3 & 2.0 & 71.0 & 0.41 & 10.5 & 0.37 & 333 \\
\hline 6 & Maize & 9.2 & 3.9 & 73.7 & 0.20 & 3.50 & 0.25 & 355 \\
\hline 7 & Rice & 7.0 & 1.0 & 78.0 & 0.20 & 3.50 & 0.18 & 345 \\
\hline
\end{tabular}

\section{Health Benefits}

Amaranth leaves are a good source of energy in the body sicne the crude protein content in the leaves ranges is very high i.e.20 to $32 \%$, on a dry weight basis. Amaranth leaves are a good source of elements like manganese, iron, copper, calcium, magnesium, potassium and phosphorus necessary to maintain adequate electrolyte balance in the body. People suffering from gluten 
intolerance or those suffering from celiac diseases can get daily recommended dose of protein from amaranth greens. Compared to other plant sources, such as wheat and rice amaranths are glutenfree and contain $30 \%$ more protein with complete set of amino acids. It can improve the digestive system and reduce constipation due to the high content of dietary fibre which is three times that of wheat. The protein in the leaves helps to reduce insulin levels in the blood and also releases a hormone that lessens hunger pranks and prevent over eating. One of the key health benefits of vegetable amaranth leaves is their cholesterol-lowering capacity. Due to the high fibre content, this leafy vegetable is effective in reducing LDL levels in the blood and promotes weight loss. Tocotrienols, a type of vitamin E available in vegetable amaranths, also contributes to its cholesterol lowering ability. Iron-rich (five times that of wheat) red amaranth leaves promote coagulation and increase haemoglobin content and red blood cell counts. It is also an excellent source of folic acid which is necessary to increase the blood haemoglobin level. Amaranth leaves are excellent dietary source of phytosterols that lowers blood pressure and prevents heart ailments including stroke. The presence of lysine (anessential amino acid) along with vitamin E, iron, magnesium, phosphorus, potassium and vitamin C helps to fight against free radicals responsible for ageing and formation of malignant cells which helps in fighting against cancer. The high calcium present in amaranth leaves (two times that of milk) is helpful to reduce risk of osteoporosis and other calcium deficiency- related disorders. Amaranth leaves are excellent source of $\beta$-carotene. Inclusion of amaranth leaves in the daily diet can help to prevent vitamin A deficiency. It was reported that the incidence of blindness in children due to malnutrition has been reduced with the consumption of 50-100 g of amaranth leaves per day Das [22].

\section{Bioactive Components and Medicinal Properties}

The health benefits of amaranths have always been recognised in homoeopathic and Ayurvedic medicines. Both the seeds and leaves of amaranth are used as herbal remedies and have nutraceutical value. Amaranth protein contains a low proportion of prolamins which makes it a safe ingredient for people with celiac disease and recent studies have shown that amaranth peptides displayed antihypertensive and anti-inflammatory activity. Peptides contained in amaranth seed proteins have shown various biological activities. Some studies using amaranth flour and protein isolates reported the occurrence of peptides with biological activities such as anti-hypertensive, anti-oxidant, anti thrombotic,anti-proliferative among others. Amaranth is ranked as one of the top five vegetables in antioxidant capacities Walter [23]). It contains ample amount of bioactive components, such as L-ascorbic acid, betacarotene, polyphenol, anthocyanins and lutein Walter[23]. It has been used as an antipyretic to reduce labour pain in Indian and Nepalese traditional medicine, as astringent, diuretic, haemorrhage and hepatoprotective agent (Kirtikar and Basu [24]. Amaranths have also been used to treat bladder distress, piles, toothache, blood disorders and dysentery (Madhav [25]. The health beneficial antioxidant activities are related to their bioactive components. The cholesterol- lowering effects in amaranth may be due to unsaturated fatty acids. Being a good source of magnesium which is effective to relax blood vessels and prevent constriction and rebound dilation, it helps to fight migraines. Cooking had no deleterious effect on total bioactive component except for the reduction of anthocyanins content. Home cooking increases the antioxidant activities and the contents of arytenoids, especially by steaming. Both simmering and blanching increased the betacarotene and lutein in the cooked amaranth (Han and Xu [26].

\section{Food Uses of Amaranth}

Vegetable amaranths are widely consumed as leafy vegetables in India and other Asian and Southeast Asian countries, also in African countries where as in North and South America grain amaranths are widely consumed. Amaranth leaves are a good source of high amount of protein, vitamins, minerals and dietary fibre. Chopped plants can also be used as forage for livestock. Amaranth seed oil has been reported to contain large amount (7-8\% and 11\%) of squalene which is often used in cosmetics and medicine, where olive oil contains only $1 \%$ of squalene. Amaranth oil is also a rich source of tocotrienols which is very effective to lower the LDL cholesterol (Becker [27] Plate and Areas [17]. In India A. hypochondriacus is known as the 'king grain' and is often popped to be used in confections. Amaranth grain may be processed in various ways, like grains can be popped, flaked, extruded and ground into flour. Popped amaranth can be enjoyed on its own or can be served with milk or soymilk and fruit for a healthy breakfast. Amaranth can be used as a substitute in porridge, stirred into soups; Amaranth grains can be cooked whole in a pot, rice cooker or pressure cooker to prepare breakfast porridge or savory 'polenta'. The grain flour or flaked grains are combined with wheat or other flours to make cereals, cookies, bread and other baked goods. As per general recommendation, amaranth grain flour should contribute only $10-20 \%$ of the mixed flour blended with wheat flour. But it has been shown that amaranth grain flour blended up to $50-75 \%$ of the mixed flour, it will still retain functional properties as well as flavour.

\section{Processing}

Amaranth is cleaned with screens, by winnowing, with a fan or other blowing device. After harvesting, it is important to further dry the crop to ensure it won't spoil during storage. It can be left on trays in the hot sun or placed near an indoor heat source. Amaranth has no hulls to remove unlike beans or true grains, Amaranth is relatively a small sized grain with average diameter of about $1 \mathrm{~mm}$. The embryo part accounts for about $25 \%$ of the kernel and situated in the peripheral region. The kernel consists of storage tissue or per sperm and the endosperm part is present as a two layered tissue Coimbra and Salema [28]. The seed coat of the amaranth grain is smooth and thin. Amaranth seed contains $26 \%$ of bran and germ components and $74 \%$ of flour. The nutrients are not uniformly 
distributed throughout the grain like other cereals. Nutrients are concentrated in bran and germ fractions of the grain. The amaranth grain can be toasted, popped, extruded or milled into flour and can therefore be consumed as such or included in other cereal products such as bread, cakes, muffins, pancakes, cookies, dumplings, crepes, noodles and crackers [29-84].

\section{Conclusion}

Amaranths especially the grain amaranths are considered as the golden crop of future. Much of the research activities done on amaranths has focussed on its exceptional nutritive value. The health benefits of amaranths have been recognized in homoeopathic and Ayurvedic medicines. Both the seeds and leaves of amaranth are used as herbal remedies and have nutraceutical value.

\section{References}

1. Bejosano FP, Corke H (1998) Protein quality evaluation of Amaranthus wholemeal flours and protein concentrates. J Sci Food and Agric 76(1): 100-106.

2. Repo-Carrasco R (2011) Andean indigenous food Crops: Nutritional value and bioactive compounds. Doctoral dissertation at University of Turku, Finland.

3. Fasano A, Catassi C (2001) Current Approaches to diagnosis and treatment of celiac disease: An evolving spectrum. Gastroenterology 120(3): 636-651.

4. Thompson T (2001) Case problem: Question regarding the acceptability of buckwheat, amaranth, quinoa, and outs from a patient with celiac disease. J Am Diet Assoc 101: 586-587.

5. Januszewska-Jóźwiak K, Synowiecki J (2008) Characteristic and suitability of amaranth components in food biotechnology. Biotechnologia 3: 89-102.

6. Sindhuja A, Sudha ML, Rahim A (2005) Effect of incorporation of amaranth fl our on the quality of cookies. Eur. Food Res. Technol 221: 597-601.

7. Grobelnik S, Turinek M, Jakop M, Bavec M, Bavec F (2009) Nutrition value and use of grain amaranth: potential future application in bread making. Agricultura 6(2): 43-53.

8. Kuhn M,Wagner S, Aufhammer W (1996) Amaranths, Buchweizen, Reismelde und Hafer. DT LebensmRundshau 92(1): 147-152.

9. Gorinstein S, Zemser M, Fliess A (1998) Computational analysis of the amino acid residue sequences of Amaranth and some other proteins. BiosciBiotechnolBiochem 62(10): 1845-1851.

10. Oleszek W, Junkuszew M, Stochmal A (1999) Determination and toxicity of saponins from Amaranthuscruentusseeds. J Agric Food Chem 47(9) 3685-3687.

11. Bolontrade AJ, Scilingo AA, Ãnón MC (2016) Amaranth proteins foaming properties: Film rheology and foam stability - Part 2. Colloids and Surfaces B: Biointerfaces 141: 643-650.

12. Ozsoy N, Yilmaz T, Kurt O, Can A, Yanardag R (2009) In vitro antioxidant activity of Amaranthuslividus L. Food Chem 116(4): 867-872.

13. Gorinstein S, Moshe R (1991) Evaluation of four amaranthus species through protein electrophoretic patterns and their amino acid composition. J Agric Food Chem 39(5): 851-854.

14. Resio ANC, Tolaba MP, Suarez C (2000) Some physical and thermal characteristic of amaranth starch. Food Sci Technol Int 65: 371-378.
15. Alvarez Jubete L, Arendt EK, Gallagher E (2010) Nutritive value of pseudocereals and their increasing use as functional gluten-free ingredients. Trends Food Sci Technol 21(2): 106-113.

16. Mendonça S, Saldiva PH, Cruz RJ, Arêas JAG (2009) Amaranth protein presents cholesterol-lowering effects. Food Chem 116(3): 738-742.

17. Plate AYA, Areas JAG (2002) Cholesterol-lowering effect of extruded amaranth (Amaranthuscaudatus L) in hypercholesterolemia rabbits. Food Chem 76: 1-6.

18. Becker R, Irving DW, Saunders RM (1986) Production of deranged amaranth flour by stone milling. Food Sci Technol Lebensm Wiss Technol 19: $372-3740$.

19. Rodas B, Bressani R (2009) The oil, fatty acid and squalene content of varieties of raw and processed amaranth grain. Arch Latinoam Nutr 59(1): 82-87.

20. Schnetzler KA, Breen WM (1994) Food uses and amaranth product research: a comprehensive review. In 0 Paredes-López (eds), Amaranth: Biology, chemistry, and technology. Boca Raton: CRC Press pp. 155-184.

21. Tosi EA, Re ED, Lucero H, Masciarelli R (2001) Dietary fiber obtained from amaranth (Amaranthuscruentus) grain by differential milling. Food Chem 73(4): 441-443.

22. Das S (2016) Amaranthus: A Promising Crop of Future, Business Media Singapore.

23. Walter CW (2001) Eat, drink and be healthy. Free Press New York p. 132.

24. Kirtikar KR, Basu BD (1987) Indian medicinal plants, (2 ${ }^{\text {nd }}$ Edn.); International Book Distributors, India, Dehra Dun pp. 2061-2062.

25. Madhav CK, Sivaji K, Tulasi RK (2008) Flowering plants of Chitoor

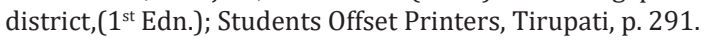

26. Han S, Xu B (2014) Bioactive Components of Leafy Vegetable Edible Amaranth (AmaranthusmangostanusL.) as Affected by Home Cooking Manner. J Food Sci Technol 2(4): 122-127.

27. Becker R, Wheeler EL, Lorenz K (1981) A compositional study of amaranth grain. J Food Sci 46: 11-75.

28. Coimbra S, Salema R (1994) Amaranthushypochiondriacus: seed structure and localisation of seed reserves. Ann Bot 74(4): 373-379.

29. Alvarez Jubete L, Auty M, Arendt EK, Gallagher E (2010) Baking properties and microstructure of pseudocereal flours in gluten free bread formulations. European Food Research and Technol, 230: 437445 .

30. Avila Sosa R, Palou E, Mungu'1a MTJ, Nev'arez Moorill'on GV, Cruz ARN, et al. (2012) Antifungal activity by vapor contact of essential oils added to amaranth, chitosan, or starch edible film. Intl J Food Microbiol 153(2): 66-72.

31. Barba de la Rosa AP, Fomsgaard IS, Laursen B, Mortensen AG, Olvera Martinez L, et al. (2009) Amaranth (Amaranthushypochondriacus) as an alternative crop for sustainable food production: phenolic acids and flavonoids with potential impact on its nutraceutical quality. J Cereal Sci 49(2): 117-121.

32. Berghofer E, Schoenlechner R (2002) Grain Amaranth. In Belton P, Taylor J (Eds.) Pseudocereals and Less Common Cereals, Grain Properties and Utilization Potential. Springer-Verlag, pp. 219-260.

33. Bhatia AL, Jain M (2003) Amaranthuspaniculatus(Linn.) improves learning after radiation stress. J Ethnopharmacol 85(1): 73-79.

34. Breene WM (1991) Food uses of grain amaranth. Cereal Food World 36(5): 426-429.

35. Bressani R (1989) The proteins of grain amaranth. Food Reviews Intl 5(1): $13-380$. 
36. Bressani R (1994) Composition and nutritional properties of amaranth. In 0 Paredes Lopez (Eds.), Amaranth. Biology, chemistry and technology. Boca Rat_on: CRC Press, Inc, pp. 185-206.

37. Burisov'a A, Dodok L, Skrovankova S, Serulova D (2001) The influence of substitution of wheat flour by amaranth flour on fermentative gas production and quality of bread. RostlinnaVyroba 47: 276-279.

38. Cabrera Ch'avez F, Calder'on de la Barca AM, Islas Rubio AR, Marti A, Marengo M, et al. (2012) Molecular rearrangements in extrusion processes for the production of amaranth-enriched, gluten-free rice pasta. LWT Food Sci Technol 47: 421-426.

39. Calder'on de la Barca AM, Rojas Mart'inez ME, Islas Rubio AR, CabreraCh'avez F (2010) Gluten-free breads and cookies of raw and popped amaranth flours with attractive technological and nutritional qualities. Plant Food Hum Nutr 65(3): 241-246.

40. Colla E, Sobral PJD, Menegalli FC (2006) Amaranthuscruentus flour edible films: influence of stearic acid addition, plasticizer concentration, and emulsion stirring speed on water vapor permeability and mechanical properties. J Agric Food Chem 54(18): 6645-6653.

41. Diaz JMR, Suuronen JP, Deegan KC, Serimaa R, Tuorila H, et al. (2015) Physical and sensory characteristics of corn-based extruded snacks containing amaranth, quinoa and ka niwa flour. LWT - Food SciTechnol 64(2): 1047-1056.

42. Early DK (1990) Amaranth Production in Mexico and Peru. In Janick J, Simon JE (eds.), Advances in new crops. Timber Press p. 140-142.

43. FAO (2005) The state of food insecurity in the world. FAO, Rome.

44. Ferreira TAPC, Matias ACG, $\mathrm{Ar}^{\wedge}$ eas JAG (2007) Nutritional and functional characteristics of amaranth (Amaranthus spp.). Nutrire 32(2): 91-116.

45. Funke M (2011) Evaluation of nutrient contents of Amaranth leaves prepared using different cooking methods. Food NutrSci 2(4): 249-252.

46. Gontard N, Guilbert S, Cuq J (1992) Edible wheat gluten films: influence of the main process variables on films properties using response surface methodology. J Food Sci 57(1): 190-195.

47. Gorinstein S, Medina-Vargas OJ, Jaramillo NO, Arnao-Salas I, MartinezAyala AL, et al. (2007) The total polyphenols and the antioxidant potentials of some selected cereals and pseudocereals. Eur. Food Res. Technol 225(4): 321-328.

48. Harlan JR (1975) Crops and man. American Society of Agronomy, Madison.

49. Keya EL, Mugambi PM (1999) The influence of amaranth substitution on pasting, dough visco-elastic and bread quality properties of Kenyan home baking grade wheat flour. DiscovInnovat 11(1): 41-49.

50. Kong X, Bao J, Corke H (2009) Physical properties of Amaranthus starch. Food Chem 113(2): 371-376.

51. Kov'acs ET, Berghofer E, Sch“onlechner R (2002) Using pseudo-cereal milling fractions for pasta production 14-17. p. 70-78.

52. Kov'acs ET, Maraz-Szabo L, Varga J (2001) Examination of the proteinemulsifier-carbohydrate interactions in amaranth-based pasta products. Acta Aliment Hung 30: 173-187.

53. Krishna A, Kumar A (2005) Evaluation of radio protective effects of Rajgira (Amaranthuspaniculatus) extract in Swiss albino mice. J Radiat Res 46(2): 233-239.

54. Lamacchia C, Camarca A, Picascia S, Di Luccia A, Gianfrani C (2014) "Cereal based Gluten free food: how to reconcile nutritional and technological properties of wheat proteins with safety for celiac disease patients". Nutrients (Review) 6(2): 575-590.

55. Lamothe LM, Srichuwong S, Reuhs BL, Hamaker BR (2015) Quinoa (Chenopodium quinoa $\mathrm{W}$ ) and amaranth (Amaranthuscaudatus L) provide dietary fibres high in pectic substances and xyloglucans. Food Chem 167: 490-496.

56. Lehmann JW, Putnam DH, Qureshi AA (1994) Vitamin-E isomers in grain amaranths (Amaranthusspp). Lipids 29(3): 177-181.

57. Leray G, Oliete B, Mezaize S, Chevallier S, De Lamballerie M (2010) Effects of freezing and frozen storage conditions on the rheological properties of different formulations of non-yeasted wheat and glutenfree bread dough. J Food Eng 100: 70-76.

58. Lopez MG, Bello-Perez LA, Peredes-Lopez O (1994) Amaranth Carbohydrates. Peredes-Lopez 0 (eds.), Amaranth Biology, Chemistry and Technology. CRC Press, Boca Raton, FL, pp. 107-132.

59. Melvin HW (2010) Nutrition for health, fitness and sport. Mc Graw-Hill p 284

60. Ogrodowska D, Zadernowski R, Czaplicki S, Derewiaka D, Wronowska B (2014) Amaranth Seeds and Products - The Source of Bioactive Compounds. Pol J Food Nutr Sci 64(3): 165-170.

61. Pa'sko P, Barton H, Zagrodzki P, Gorinstein S, Fołta M, Zachwieja Z (2009) Anthocyanins, total polyphenols and antioxidant activity in amaranth and quinoa seeds and sprouts during their growth. Food Chem 115: 994-998.

62. Pal J, Singhal RS, Kulkarni PR (2001) Physicochemical properties of hydroxypropyl derivative from corn and amaranth starch. Carbohydr Polym 48(1): 19-53.

63. Paredes-Lopez O, Cervantes-Ceja ML, Vigna-Perez M et al (2010) Berries: improving human health and healthy aging and promoting quality life: a review. Plant Foods Hum Nutr 65(3): 299-308.

64. Pedersen B, Bach Knudsen K, Eggum B (1990) The nutritive value of amaranth: Energy and fiber of raw and processed grain. Plant Foods for Human Nutr 40(1): 61-71.

65. Rivera G, Bocanegra-Garcia V, Monge A (2010) Traditional plants as source of functional foods, a review. CyTAJ Food 8(2): 159-167.

66. Rizzello CG, Coda R, De Angelis M, Di Cagno R, Carnevali P, et al. (2009) Long-term fungal inhibitory activity of water-soluble extract from Amaranthus spp. seeds during storage of gluten-free and wheat flour breads. Intl J Food Microbiol 131(3): 189-196.

67. Samiyi M, Ashraf HRL (2007) Iranian breads supplemented with amaranth flour. Intl J Food Sci Technol 28(6): 625-628.

68. Sanz-Penella JM, Laparra JM, Sanz Y, Haros M (2012) Bread supplemented with amaranth (Amaranthuscruentus): Effect of phytates on in vitro iron absorption. Plant Foods Hum Nutr 67: 50-56.

69. Sanz-Penella JM, Wronkowska M, Soral-Smietana M, Haros M (2013) Effect of whole amaranth flour on bread properties and nutritive value. LWT Food SciTechnol 50: 679-685.

70. Schnetzler KA, Breene WM (1995) Food uses and amaranth product research: a comprehensive review. In: Peredes-Lopez O (eds.), Amaranth biology, chemistry and technology. CRC Press Boca Raton FL: 155-184.

71. Schoenlechner R, Mandala I, Kiskini A, Kostaropoulos A, Berghofer E (2010) Effect of water, albumen and fat on the quality of gluten-free bread containing amaranth. Intl J Food Sci Technol 45: 66166-66167.

72. Schoenlechner R, Wendner M, Siebenhandl-Ehn S, Berghofer E (2010) Pseudocereals as alternative sources for high folate content in staple foods. J Cereal Sci 52: 475-479.

73. Shevkani K, Singh N, Kaur A, Rana JC (2014) Physicochemical, pasting, and functional properties of amaranth seed flours: effects of lipids removal. J Food Sci 79(7): 1271-1277.

74. Souci SW, Fachman W, Kraut H (2000) Food composition and nutritional table. WissenschaftVerlago $\mathrm{GmbH}$, Stuttgart. 
75. Svobadova A, Psotova J, Walterova D (2003) Natural phenolics in the prevention of UV-induced skin damage. A review. Biomed Pap 147(2): 137-145.

76. Tapia-Bl'acido DR, Sobral PJA, Menegalli F (2013) Effect of drying conditions and plasticizer type on some physical and mechanica properties of amaranth flour films. LWT-Food Sci Technol 50(2):392400.

77. Tapia-Blácido D, Mauri A, Menegalli FC, Sobral PJA (2005) Development and characterization of edible films based on amaranth flour (Amarantuscaudatus). J Food Engineering 67: 215-223.

78. Tapia-Blácido D, Sobral PJA, Menegalli FC (2005) Development and characterization of biofilms based on amaranth flour (Amaranthuscaudatus). J Food Engineering 67(2): 215-223.

79. Tironi VA, A non M (2010) Amaranth proteins as a source of antioxidant peptides: effect of proteolysis. Food Res Int 43(1): 315-322.
80. Venskutonis PR, Kraujalis P (2013) Nutritional Components of Amaranth Seeds and Vegetables: A Review on Composition, Properties, and Uses. Comprehensive Reviews in Food Science and Food Safety 12: 381-412.

81. Vitali D, Dragojevi'c IV, `Seběci'c B (2008) Extractable phenolic compounds and anti oxidative properties of different wheat-based integral biscuits. In: Curic D, Eds. Proceedings of the 2008 Joint Central European Congress 1: 407-412.

82. Wallace TC (2011) Anthocyanins in cardiovascular disease. Adv Nutr 2(1): 1-7.

83. Wayne RB, Stanley TO, Mark SM (2000) Phyto chemicals as bioactive agents. CRC Press, Lancaster.

84. Williams JT, Brenner D (1995) Grain amaranth (Amaranthus species) In: Williams JT (Eds), Underutilized Crops: Cereals and Pseudocereals. Chapman \& Hall London UK: 129-187.

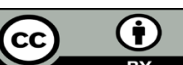

This work is licensed under Creative

Commons Attribution 4.0 License

Submission Link:

$$
\text { Submit Article }
$$

DOI: $10.32474 /$ CDVS.2018.01.000112

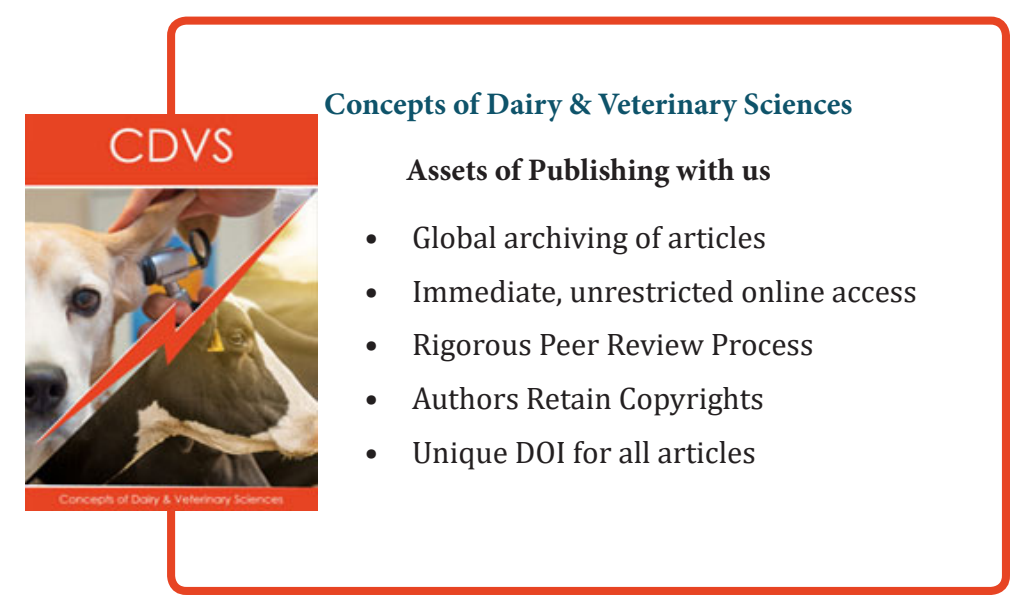

